\title{
Allozyme variation in natural populations of Picea glehnii in Hokkaido, Japan
}

\author{
ZHANG M. WANG* \& KAZUTOSHI NAGASAKA \\ Forest Genetics Laboratory, Forestry and Forest Products Research Institute, Hokkaido Research Center, \\ Hitsujigaoka 7, Toyohira, Sapporo 062, Japan
}

\begin{abstract}
Current-year needles from individual trees were used to study the genetic diversity in 10 natural populations of Picea glehnii (Masters) in Hokkaido, Japan, by polyacrylamide gel electrophoresis. Data from 12 polymorphic loci encoding 33 alleles identified by nine enzyme systems were analysed. Mean number of alleles per locus, percentage polymorphic loci and observed and expected heterozygosities were $1.98,75$ per cent, 0.08 and 0.088 , respectively. These genetic parameters varied considerably among populations. Diversity among the populations was small with a mean $F_{\mathrm{ST}}$ of 0.022 and genetic distance of 0.0017 . However, a $\chi^{2}$-test showed that allele frequencies were different $(P<0.05)$ among the populations at 10 of the 12 loci; cluster and canonical discriminant analyses indicated that some of the populations were very different from others; and correlation analyses revealed significant relationships between some of the allele frequencies and longitude, latitude and altitude. Results suggest that genetic variation in $P$. glehnii is both geographically clinal and population-specific.
\end{abstract}

Keywords: allozyme variation, discriminant analysis, genetic diversity, Picea glehnii, population genetics.

\section{Introduction}

Picea glehnii (Masters) is one of only two native spruce species in Hokkaido, Japan, where it grows in many types of habitats over a wide range of distribution. However, outside Hokkaido, only one very small population of the species has been found in the Hayachine mountains of northern Honshu, whereas outside Japan, it grows in the southern Kuriles to about $147^{\circ} \mathrm{E}$ and southern Sakhalin to about $47^{\circ} \mathrm{N}$ (Horikawa, 1972). Mature trees of $P$. glehnii may reach $40 \mathrm{~m}$ in height and $1.5 \mathrm{~m}$ in diameter (d.b.h.; Sato, 1990). Being a very important forest tree species, it has been planted in large areas of Hokkaido in recent years (Matsuda, 1989). Tree improvement programmes, seed orchards and genetic conservation stands have been established for the species in Hokkaido. To manage and utilize the genetic resources of $P$. glehnii more effectively,

\footnotetext{
*Correspondence: Department of Biology, McGill University, 1205 Avenue Docteur Penfield, Montreal, PQ, Canada, H3A 1B1. E-mail: mingz@bio1.lau.mcgill.ca

$\dagger$ Present address and author for reprints: Genetic Analysis Laboratory, Forestry and Forest Products Research Institute, Matsunosato 1, Kukizaki, Ibaraki 305, Japan.
}

genetic information about the species is urgently needed. To encourage genetic studies of the species, the Hokkaido Regional Breeding Office, Forest Tree Breeding Institute, Japan, has been organizing meetings on the genetics of spruce species in Hokkaido since 1993. However, only three related studies have been reported. Okada (1975) studied geographical variation in seedling height and bud opening phenology from 12 seed sources of $P$. glehnii in a common garden experiment. Two other studies examined the inheritance and linkage of isozymes in seed megagametophytes (Kubota et al., 1993; Wang et al., 1996). Here, for the first time, we report allozyme variation in 10 natural $P$. glehnii populations in Hokkaido.

\section{Materials and methods}

Current-year needles were collected from at least 59 mature trees in each of 10 natural $P$. glehnii stands throughout Hokkaido in the late autumn and early winter of 1994 (Fig. 1). All stands were widely separated from each other, except stands Jozankei A and B, which were only about $2 \mathrm{~km}$ apart (Fig. 1). In each stand, efforts were made to collect needles from widely spaced large trees. Samples were put in 


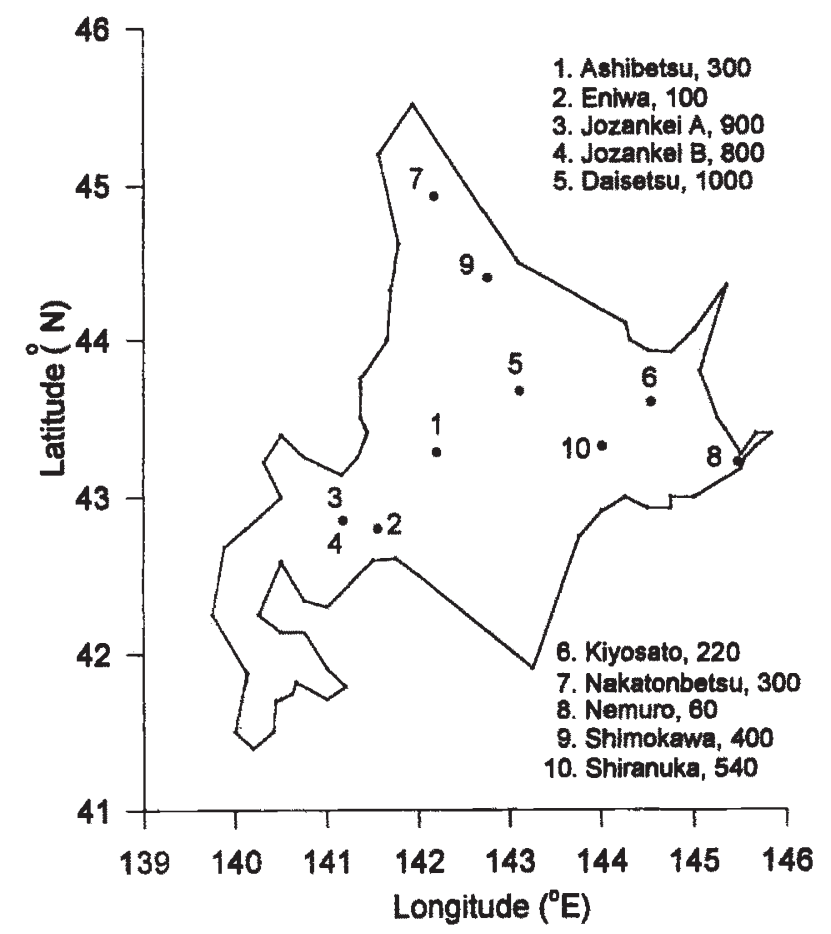

Fig. 1 Stand locations of Picea glehnii on a schematic map of Hokkaido. Numbers following stand names are altitudes (m).

plastic bags in ice containers, taken to the laboratory and then stored at $-20^{\circ} \mathrm{C}$ until needed. Needle material preparation and polyacrylamide gel electrophoresis followed the methods of Tsumura et al. (1990). Designations of the loci and alleles followed those of Wang et al. (1996). Seed megagametophyte homogenates were loaded onto the same gels to verify that isozyme loci detected in the needles corresponded to those observed in the seed (Wang et al., 1996). If the zones of activity overlapped, they were inferred to belong to the same loci, and the megagametophyte locus designations were used for the needles. The nine enzyme systems surveyed and the loci and alleles detected, scored and analysed are: 6-phosphogluconic dehydrogenase $\left(6 p g d^{\text {a.b }}\right)$, alanine aminopeptidase $\left(\right.$ Aap $\left.-3^{\mathrm{a}, \mathrm{b}}\right)$, diaphorase (Dia-2 $2^{\mathrm{a}, \mathrm{b}}$, Dia- $\left.3^{\mathrm{a}, \mathrm{b}}\right)$, esterase $\left(E s t-1^{\mathrm{a}, \mathrm{b}, \mathrm{c}}\right.$, Est $\left.^{\mathrm{a}} \mathrm{2}^{\mathrm{a}, \mathrm{b}, \mathrm{c}}\right)$, fumarase $\left(F m^{\mathrm{a}, \mathrm{b}}\right)$, glycerate dehydrogenase $\left(G 2 d h^{\text {a,b.c }}\right)$, leucine aminopeptidase (Lap $\left.{ }^{\text {a,b,c,d }}\right)$, menadione reductase $\left(M n r-2^{\mathrm{a}, \mathrm{h}}\right)$ and shikimate dehydrogenase $\left(S h d h-1^{\text {a,b.c,d,e }}, \quad S h d h-2^{\text {a,b,c }}\right)$. Three enzymes (glucose-6-phosphate dehydrogenase, G6PD; glutamic-oxaloacetic transaminase, GOT; and sorbitol dehydrogenase, SODH) that stained well in seed gels were also stained in this study (Wang et al., 1996). However, their stainings were too poor to interpret so that they were not scored.
Data were analysed using Blosys-1 (Swofford \& Selander, 1989) to obtain the mean number of alleles per locus $\left(A_{\mathrm{p}}\right)$, percentage of polymorphic loci $\left(P_{\mathrm{p}}\right), F$-statistics (Wright, 1965), genetic distance (Nei, 1978), observed and expected heterozygosities based on Hardy-Weinberg expectation $\left(H_{\mathrm{o}}, H_{\mathrm{e}}\right)$, and cluster analysis based on genetic distance (Nei, 1978) using the unweighted pair-group method. Genetic diversity at the population level was measured by the means of $A_{\mathrm{p}}, P_{\mathrm{p}}, H_{\mathrm{o}}$ and $H_{\mathrm{e}}$ across all the populations. At the species level, these were obtained by analysing all the populations as one unit. Wang et al. (1996) used seeds from 38 trees to study the inheritance and linkage relationships of isozymes in $P$. glehnii. The genotypes of these 38 trees they observed were also analysed as one unit to obtain these four parameters.

Correlation analysis (SAS, 1988) was used to examine whether $A_{\mathrm{p}}, P_{\mathrm{p}}, H_{\mathrm{o}}, H_{\mathrm{e}}$ and allele frequencies, except the least common allele at each locus, were related to geographical parameters (latitude, longitude and altitude) of the populations. PROC DISCRIM (discriminant procedure) with the CAN (canonical) option in SAS (SAS, 1988) was used to detect possible variation patterns of the populations. To do this, the genotypes of individual trees were transformed to allozyme profiles according to Yeh et al. (1985).

\section{Results}

\section{Enzymes and their stainings}

Except G2DH, the inheritance of all isozymes has been examined for $P$. glehnii using seed megagametophytes, and no significant linkages among the loci scored and analysed in this study were detected by Wang et al. (1996). However, the inheritance of G2DH has been demonstrated in other conifers (Cheliak \& Pitel, 1984; Shiraishi, 1988; Na'iem et al., 1989; Suyama et al., 1992). All the loci, except Est-2, detected in the needles corresponded to those observed in seed megagametophytes (Wang et al., 1996). However, Aap-4 and Dia-4, detected in seed, did not show staining activities on needle gels. Aap-1, Aap-2, Dia-1, Got-1, Got-2, Got-3 and Mnr-1 did not stain consistently clearly enough for interpretation in needle tissue from all the populations and trees and were excluded from data analyses. G6PD, GOT and SODH were also stained too poorly to score in needles. Thus, in general, the number of enzymes and loci of some of the enzymes that stained well enough to score were fewer in needles than in seeds (Wang et al., 1996). However, 
the number of alleles observed at equivalent loci was very similar in both tissues of $P$. glehnii. Some of our poor stainings were caused by long storage time of the needles. Therefore, such storage should be avoided as much as possible for similar kinds of studies.

\section{Allele frequencies and genetic variabilities}

For the nine enzymes, 12 loci with 33 alleles could be scored consistently. At each locus, at least two alleles were observed in at least one population, and the most frequent allele was the same among all the populations. However, six private alleles were detected in four of the 10 populations (Table 1). A complete table of the allele frequencies is available on request.

Genetic variability measures varied greatly among the populations (Table 1). The Nemuro population had the lowest $A_{\mathrm{p}}, P_{\mathrm{p}}$ and $H_{\mathrm{o}}$ values and the second smallest $H_{\mathrm{e}}$ value. The Eniwa population had much greater $H_{\mathrm{o}}$ and $H_{\mathrm{e}}$ than the rest and was the only population without a deficiency of heterozygotes. The $\chi^{2}$-test indicated that the populations were different $(P<0.05)$ in their allele frequencies at all the loci analysed, except at Dia-2 $(P=0.477)$ and at Lap $(P=0.062)$. However, genetic distances were

Table 1 Genetic variability in Picea glehnii

\begin{tabular}{lcrccc}
\hline Population & $A_{\mathrm{p}}$ & \multicolumn{1}{c}{$P_{\mathrm{p}}$} & $H_{\mathrm{o}}$ & $H_{\mathrm{e}} \dagger$ & $P_{\mathrm{a}}$ \\
\hline Ashibetsu & 2.0 & 75.0 & 0.084 & 0.091 & 0 \\
Eniwa & 2.0 & 83.3 & 0.132 & 0.124 & 2 \\
Jozankei A & 2.0 & 83.3 & 0.078 & 0.080 & 1 \\
Jozankei B & 1.8 & 66.7 & 0.079 & 0.085 & 0 \\
Daisetsu & 2.3 & 83.3 & 0.078 & 0.083 & 2 \\
Kiyosato & 1.8 & 58.3 & 0.070 & 0.089 & 1 \\
Nakatonbetsu & 2.1 & 83.3 & 0.078 & 0.088 & 0 \\
Nemuro & 1.6 & 50.0 & 0.055 & 0.076 & 0 \\
Shimokawa & 2.3 & 100.0 & 0.087 & 0.092 & 0 \\
Shiranuka & 1.9 & 66.7 & 0.057 & 0.072 & 0 \\
Mean $¥$ & 1.98 & 75.0 & 0.080 & 0.088 & \\
Species§ & 2.8 & 100.0 & 0.081 & 0.089 & \\
Seedף & 2.7 & 95.2 & 0.209 & 0.213 & \\
\hline
\end{tabular}

$A_{\mathrm{p}}$, number of alleles per locus; $P_{\mathrm{p}}$, percentage

polymorphic loci (criterion 0.99); $H_{\mathrm{o}}$ and $H_{\mathrm{e}}$, observed and expected heterozygosity; $P_{\mathrm{a}}$, private allele.

$\dagger$ Unbiased estimate (Nei, 1978).

\$Mean across all the populations.

$\S$ Analysis was performed by treating all the populations as one unit.

IGenotypes were from seed megagametophytes of 38 trees (Wang et al., 1996). very small, ranging from 0.000 to 0.005 with a mean of $0.0017 . F_{\mathrm{ST}}$ values varied from 0.006 at Dia-2 to 0.075 at $6 p g d$, and overall, only 2.2 per cent of the variation was attributable to the differences among the populations. Complete tables for the $\chi^{2}$-test, $F$-statistics and genetic distance are available on request.

The 10 populations are grouped into three clusters (Fig. 2). The Eniwa population is distinct, and the other populations form two clusters with four and five populations, respectively (Fig. 2). However, compared with the distributions of the populations (Fig. 1), these clusters do not indicate any clear patterns of geographical variation among the populations.

In canonical discriminant analysis, the first five of the nine possible discriminant functions are significant in separating the populations (Table 2). The first two of the five functions accounted for $57.6 \mathrm{per}$ cent of the total variance, and 44 per cent (cumulative $r^{2}$ ) of this was caused by differences among the populations. This means that the first two functions account for more than 25 per cent (57.6 per cent $\times 44$ per cent $\times 100$ per cent) of the total intrapopulation variance. A scatter plot using the first two functions indicates that the 10 populations belong to three distinct groups: the Eniwa population; the Kiyosato population; and the rest (Fig. 3).

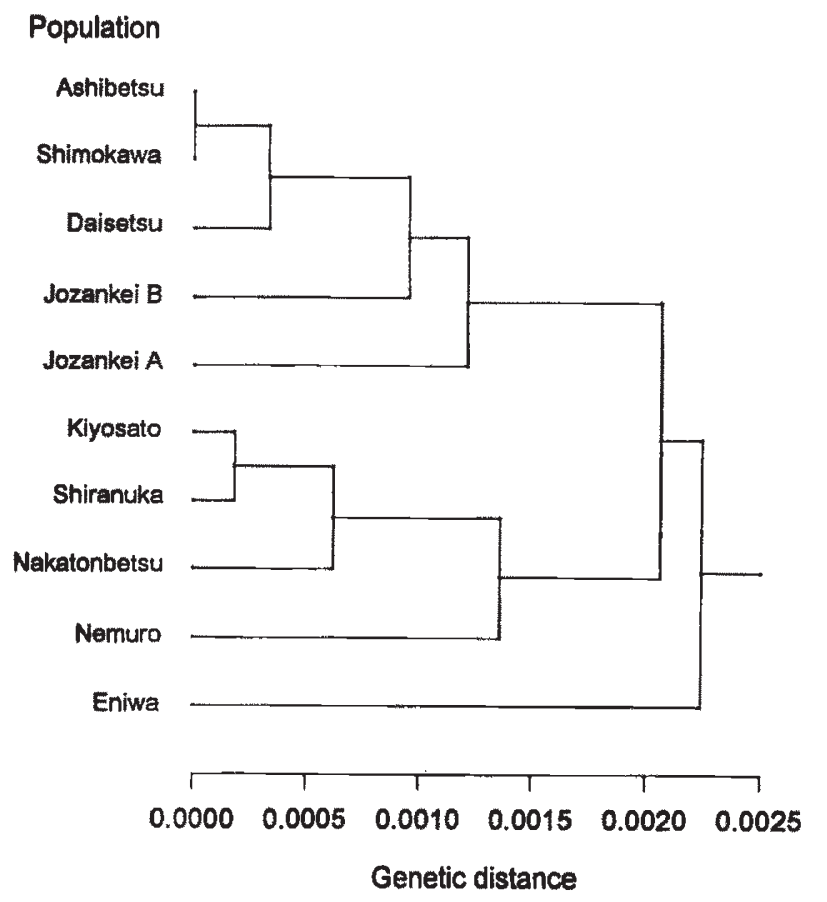

Fig. 2 Dendrogram for Picea glehnii populations based on genetic distance (Nei 1978). 
Table 2 Statistics for the five significant canonical discriminant functions (CDFs)

\begin{tabular}{lcccrc}
\hline CDF & $\begin{array}{c}\text { Percentage of } \\
\text { variance }\end{array}$ & $r^{2}$ & $C r^{2}$ & d.f. & $P>F$ \\
\hline 1 & 34.71 & 0.2558 & 0.2558 & 189 & 0.0001 \\
2 & 22.90 & 0.1849 & 0.4407 & 160 & 0.0001 \\
3 & 11.19 & 0.0997 & 0.5404 & 133 & 0.0001 \\
4 & 8.95 & 0.0814 & 0.6218 & 108 & 0.0018 \\
5 & 8.28 & 0.0758 & 0.6976 & 85 & 0.0284 \\
\hline
\end{tabular}

$r^{2}$, squared canonical correlation; $C r^{2}$, cumulative $r^{2}$.

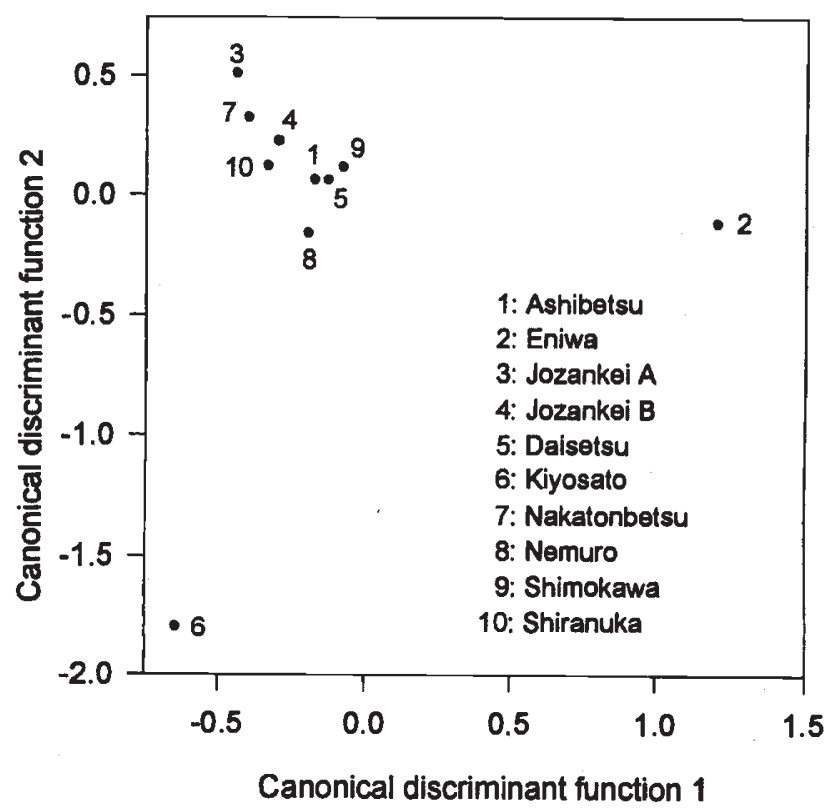

Fig. 3 Scatter plot of Picea glehnii populations on the axes of the first two canonical discriminant functions.

As in the cluster analysis, these groups do not indicate any clear patterns of geographical variation among the 10 populations.

Correlation analysis indicated that longitude, latitude and altitude were not significantly $(P<0.05)$ correlated among themselves or with $A_{\mathrm{p}}, P_{\mathrm{p}}, H_{\mathrm{o}}$ and $H_{\mathrm{e}}$. However, six (50 per cent) of the 12 loci had significant correlations with the geographical variables. Specifically, they were allele frequencies at $\operatorname{Lap}^{\mathrm{a}} \quad(r=0.698, \quad P=0.025), \quad S h d h-1^{\mathrm{b}} \quad(r=0.861$, $P=0.001)$ and $S h d h-2^{\mathrm{a}}(r=0.708, P=0.021)$ with longitude, at $F^{\mathrm{a}}(r=0.644, P=0.044), G 2 d h^{\mathrm{a}}$ $(r=0.648, \quad P=0.042), \quad$ Shdh $-1^{\mathrm{a}} \quad(r=-0.686$, $P=0.028)$ and $S h d h-1^{\mathrm{c}}(r=0.634, P=0.048)$ with latitude, and at Dia- $3^{\mathrm{a}}(r=0.802, P=0.005)$ and Shdh $-I^{\mathrm{a}}(r=0.698, P=0.024)$ with altitude. The total number of pairwise correlations was 63 for allele frequencies, and the number of significant correlations found was nine, which is about three times as many as would be expected at the 0.05 significance level and therefore cannot be a result of chance alone. A complete table of the correlation coefficients is available on request.

\section{Discussion}

Heterozygosities observed in needles and in seeds

$A_{\mathrm{p}}$ and $P_{\mathrm{p}}$ observed in seeds are very similar to those at the species level in needles (Table 1). However, the $H_{\mathrm{o}}$ and $H_{\mathrm{e}}$ at either the population or species levels obtained in needles are much lower than those in seeds (Table 1). Even when only the loci in common between both data sets are compared, $H_{\mathrm{o}}$ and $H_{\mathrm{e}}$ are 0.156 and 0.174 , respectively, from seeds, which are still much greater than from needle tissue ( 0.07 and 0.079 at the species level, and 0.07 and 0.077 at the population level). Because both seed megagametophytes and needles represent the genetic make-up of maternal trees, they should give similar results, but they did not. The possible reason for the lower heterozygosities observed in the needles compared with the megagametophytes might be because the seeds used by Wang et al. (1996) were obtained from plus trees that might have higher heterozygosities than others. Allozyme heterozygosity has been found to be positively correlated with growth (Bush \& Smouse, 1992) and fitness (Hertel \& Kohlstock, 1994) in many tree species. Clearly, this hypothesis deserves further studies.

\section{Genetic diversity at population and species levels}

The average $A_{\mathrm{p}}, P_{\mathrm{p}}$ and $H_{\mathrm{e}}$ were found to be 2.38 , 71.1 per cent and 0.169 , respectively, at the species level and 1.83, 53.4 per cent and 0.151 , respectively, at the population level in gymnosperms (Hamrick $e t$ al., 1992). Thus, at both levels observed in needles, $P$. glehnii had greater $A_{\mathrm{p}}$ and $P_{\mathrm{p}}$ but smaller $H_{\mathrm{e}}$ (Table 1) than the above. However, all these diversity measures obtained in seeds (Table 1) were higher than the above. Overall, the genetic diversity of $P$. glehnii is compatible with other conifers.

\section{Genetic diversity among populations}

The genetic diversity among the $P$. glehnii populations (mean $F_{\mathrm{ST}}=2.2$ per cent) is lower than the mean ( 7.3 per cent) of other gymnosperms (Hamrick et al., 1992). The low genetic diversity 
among populations in $P$. glehnii might be caused by long life span, wide distribution, outcrossing mating system and widely dispersed seeds (Hamrick et al., 1992). Nevertheless, four of the 10 populations had private alleles; the $\chi^{2}$-test indicated that the populations were significantly different in allele frequencies at 10 of the 12 loci analysed; and five canonical discriminant functions could separate them significantly. Therefore, a small but significant component of the diversity resides among the populations of $P$. glehnii, as observed in many other conifers (El-Kassaby, 1991).

The Nemuro population has the smallest $A_{\mathrm{p}}, P_{\mathrm{p}}$, $H_{\mathrm{o}}$ and the smallest number of variable loci among the 10 populations. It seems to have the lowest within-population genetic diversity. This population is the only one growing in a lowland habitat. Compared with other highland habitats, the harsh environmental conditions (high water level, cold soil and low nutrient content) in such a habitat (Payandeh, 1973) might have imposed strong selection pressure, resulting in reduced genetic diversity in the Nemuro population. However, according to the $H_{\mathrm{o}}$ and $H_{\mathrm{e}}$ values (Table 1), the Eniwa population seems to be the most different from the others. This is also confirmed by the results from cluster and discriminant analyses (Figs 2 and 3). Moreover, the latter analysis also indicates that the Kiyosato population is very different from the others and from Eniwa (Fig. 3). However, there are no plausible ecological explanations as to why these two populations could be more different from each other and. from the other populations.

Nevertheless, the above results indicate that there are population-specific variations in $P$. glehnii. Such variation could be caused by founder effects, mutation, genetic drift (Allendorf \& Phelps, 1981) and/or balancing selection for microgeographical differentiation (Hamrick \& Allard, 1972), together with limited gene exchange among $P$. glehnii populations owing to isolation by the mountains. No matter what the exact reasons may be, such a population-specific variation might have local adaptive significance.

On the other hand, Hokkaido is mountainous with a total area of $78510 \mathrm{~km}^{2}$. A central mountain range divides it into two parts: east and west. In winter, the north-west is characterized by severe cold and heavy snowfall. In summer, tropical air masses result in a warm climate in the south-west, while other parts are under the influence of subpolar air masses (Nakamura et al., 1986). Regionally, mean monthly temperature varies from -2 to $-8^{\circ} \mathrm{C}$ in January and 14 to $19^{\circ} \mathrm{C}$ in July; and annual precipitation ranges from 600 to $2000 \mathrm{~mm}$ (Igarashi, 1994). In such a variable climate, therefore, it is not surprising that there was significant geographical variation in allele frequencies at some loci among the $P$. glehnii populations. Generally, different alleles are correlated with different geographical parameters except $S h d h-1^{\text {a }}$. However, the frequency of $S h d h-1^{\text {a }}$ is negatively associated with latitude, but positively associated with altitude. Therefore, it is possible that these geographical parameters represent different ecological gradients that have selected different alleles or the same alleles in different ways in $P$. glehnii populations. Even if allozymes are neutral, natural selection can affect them indirectly if they are linked to genes associated with fitness. In other conifers, allozyme variations have also been found to be associated with ecological gradients on regional or small geographical scales (Mitton et al., 1977, 1980; Bergmann, 1978; Yeh \& O'Malley, 1980; El-Kassaby \& Sziklai, 1982; Hamrick et al., 1989; Schuster et al., 1989; Aguinagalde \& Bueno, 1994). Differences in bud opening phenology between east and west seed sources and among populations within each source have been observed in P. glehnii (Okada, 1975).

Overall, the results of this study indicate that there is geographical variation among $P$. glehnii populations. Within such a general pattern, there is also population-specific variation. This genetic structure has also been described for Thuja orientalis (Xie et al., 1992). Therefore, it is suggested that genetic conservation, tree improvement programmes and seed use in reafforestations should emphasize local sources. However, germplasm collections should cover the whole range to assure adequate sampling of the genome of $P$. glehnii.

In this study, it is clear that different genetic parameters and analysis methods can give similar and/or different variation patterns among populations. Results obtained from them complement for each other. Therefore, they should be used together to examine genetic diversities among populations in similar kinds of studies.

\section{Acknowledgements}

A STA fellowship from the Government of Japan to the senior author made this project possible. $\mathrm{K}$. Tanaka and Y. Sakamoto helped in tissue preparation and gel electrophoresis. T. Matsuzaki and K. Ishida helped to collect the needles. Support in various aspects from $\mathrm{K}$. Nakamura in our laboratory is greatly appreciated. The regional forest management offices in Hokkaido permitted and/or led us to their forests to collect needles. 


\section{References}

AGUiNAGALDE, I. AND BUENO, M. A. 1994. Morphometric and electrophoretic analysis of two populations of European black pine (Pinus nigra Arn.). Silvae Genet., 43, 195-199.

ALlENDORF, F. W. AND PHELPS, S. R. 1981. Use of allelic frequencies to describe population structure. Can. J. Fish. Aquat. Sci., 38, 1507-1514.

BERgMANN, F. 1978. The allelic distribution at an acid phosphatase locus in Norway spruce (Picea abies) along similar climatic gradients. Theor. Appl. Genet., 52, 57-64.

BUSH, R. M. AND SMOUSE, P. E. 1992. Evidence for the adaptive significance of allozyme in forest trees. New Forests, 6, 179-196.

CHELIAK, W. M. AND PITEL, J. A. 1984. Genetic control of allozyme variants in mature tissues of white spruce trees. J. Hered., 75, 34-40.

EL-KASSABY, Y. A. 1991. Genetic variation within and among conifer populations: review and evaluation of methods. In: Fineschi, S., Malvolti, M. E., Cannata, F. and Hattemer, H. (eds) Biochemical Markers in the Population Genetics of Forest Trees, pp. 61-76. SPB Academic Publishing, The Hague.

EL-KASSABY, Y. A. AND SZIKLAI, O. 1982. Genetic variation of allozyme and quantitative traits in a selected Douglas fir (Pseudostuga menziesii var. menziesii (Mirb.) Franco) population. Forest Ecol. Man., 4, 115-126.

HAMRICK, J. L. AND ALLARD, R. w. 1972. Microgeographical variation in allozyme frequencies in Avena barbata. Proc. Natl. Acad. Sci., U.S.A., 69, 2100-2104.

HAMRICK, J. L., BLANTON, H. M. AND HAMRICK, K. J. 1989. Genetic structure of geographically marginal populations of ponderosa pine. Am. J. Bot., 76, 1559-1568.

HAMRICK, J. L., GODT, M. J. W. AND SHERMAN-BROYLES, S. L. 1992. Factors influencing levels of genetic diversity in woody plant species. New Forests, 6, 95-124.

HERTEL, H. AND KOHLSTOCK, N. 1994. Different genetic structures of two morphological types of Scots pine (Pinus sylvestris L.). Silvae Genet., 43, 268-272.

HORIKAWA, Y. 1972. Atlas of the Japanese Flora. Gakken Co. Ltd., Japan (in Japanese).

IGARASHI, Y. 1994. Quaternary forest and climate history of Hokkaido, Japan, from marine sediments. Quaternary Sci. Rev., 13, 335-344.

KuBOTA, M., UBUKATA, M. AND TANDO, O. 1993. Inheritance of isozyme variants in Picea glehnii. Trans. Meeting in Hokkaido Br. J. Jap. For. Soc., 41, 178-180 (in Japanese).

MATSUDA, K. 1989. Regeneration and growth in the Picea glehnii forest. Res. Bull. Coll. Exp. For., Hokkaido Univ., 46, 595-717.

MITTON, J, B., LINHART, J. L., HAMRICK, J. L. AND BECKMAN, J. 1977. Population differentiation and mating system in Ponderosa pine of the Colorado Front Range. Theor. Appl. Genet., 48, 27-34.

MITTON, J. B., STURGEON, K. B. AND DAVIS, M. L. 1980.
Genetic differentiation in ponderosa pine along a steep elevational transect. Silvae Genet., 29, 100-103.

NA'IEM, M., TSUMURA, Y., UCHIDA, K., NAKAMURA, T., SHIMIZU, S. AND OHBA, K. 1989. Inheritance of isozyme variants of megagametophyte in Japanese red pine. $J$. Jap. For. Soc., 71, 425-434.

NAKAMURA, K., KIMURA, R. AND UChiJima, z. 1986. Climate of Japan. Iwanami Shoten, Japan (in Japanese).

NEI, M. 1978. Estimation of average heterozygosity and genetic distance from a small number of individuals. Genetics, 89, 583-590.

OKADA, s. 1975. Geographic variation in Picea glehnii. I. Differences in seedling height and bud-opening date among 12 seed sources. J. Jap. For. Soc., 57, 305-310.

PAYANDEH, B. 1973. Analysis of forest drainage experiment in northern Ontario. I. Growth analysis. Can. J. Forest Res., 3, 387-398.

SAS 1988. Release 6.03 edition. SAS Institute Inc., Cary, NC.

SATo, T. 1990. Trees and Shrubs of Hokkaido. Arisu, Japan (in Japanese).

SCHUSTER, W. S., ALles, D. L. AND MitTon, J. B. 1989. Gene flow in limber pine: evidence from pollination phenology and genetic differentiation along an elevational transect. Am. J. Bot., 76, 1395-1403.

SHIRAISHI, s. 1988. Inheritance of isozyme variations in Japanese black pine, Pinus thunbergii Parl. Silvae Genet., 37, 93-100.

SUYAMA, Y., TSUMURA, Y. AND OHBA, K. 1992. Inheritance of isozyme variants and allozyme diversity of Abies mariesii in three isolated natural forests. J. Jap. For. Soc., 74, 65-73.

SWOFFORD, D. L. AND SELANDER, R. B. 1989. BIOSYS-1. $A$ Computer Program for the Analysis of Allelic Variation in Population Genetics and Biochemical Systematics. Release 7. University of Illinois, Urbana, IL.

TSUMURA, Y., TOMARU, N., SUYAMA, Y., NA'IEM, M. AND OHBA, K. 1990. Laboratory manual of isozyme analysis. Bull. Tsukuba University of For, 6, 63-95 (in Japanese).

WANG, Z. M., NAGASAKA, K. AND TANAKA, K. 1996. Inheritance and linkage relationships of isozymes of Picea glehnii (Master). Silvae Genet., 45, 136-141.

WRIGHT, s. 1965 . The interpretation of population structure by $F$-statistics with special regard to systems of mating. Evolution, 19, 395-420.

XIE, C. Y., DANCIK, B. P. AND YEH, F. C. 1992. Genetic structure of Thuja orientalis. Biochem. Syst. Ecol., 20, 433-441.

YEH, F. C., CHELIAK, W. M., DANCIK, B. P., ILLINGWORTH, K., TRUST, D. C. AND PRYHITKA, B. A. 1985. Population differentiation in lodgepole pine, Pinus contorta spp. latifolia: a discriminant analysis of allozyme variation. Can. J. Genet. Cytol., 27, 210-218.

YEH, Y. C. AND O'MALLEY, D. 1980. Enzyme variation in natural populations of Douglas-fir, Pseudotsuga menziesii (Mirb.) Franco, from British Columbia. 1. Genetic variation patterns in coastal populations. Silvae Genet., 29, 83-92. 